\title{
Disadvantages and solutions of a model in asylum seeker education: Temporary education centers (TECs)
}

\author{
Duran MAVI* \\ Ministry of National Education, Ankara, Turkey \\ ORCID: 0000-0001-7244-6448
}

Article history

Received:

12.09.2021

Received in revised form: 27.11.2021

Accepted:

21.12.2021

Key words:

Asylum seeker, Syrian, TEC Turkey.
The violence, and instability because of civil war in Syria have caused millions of people to leave their country. Many countries have been affected from this migration. Turkey is one of the countries that has been significantly affected from this crisis. Turkey is trying to provide some services to Syrian people. Education is one of them. For education of this large population the schools called temporary education centers (TECs) were established by Turkish government. In this way, it is aimed to integrate Syrian asylum seekers children into the Turkish education system. But, TECs have major disadvantages on issues such as bureaucracy, school building, and student absenteeism. Simultaneously, various solutions are employed to overcome these disadvantages. In the current research, TECs' disadvantages, and solution proposal; which developed for Syrian asylum seeker children into Turkish education system were investigated. The investigations performed in a TEC, which located in Elbistan district of Kahramanmaras province in Turkey. Phenomenology was used in the research, and a semi-structured interview form developed by the researcher was used. Participants were determined through convenience sample approach. In this context, the opinions of six TEC employees, including Syrian educators who shared the same fate with Syrian asylum seeker children, were sought. The findings show TECs are intertwined with disadvantages such as lack of school building, overcrowded classrooms, limited social, and cultural activities, and lessening environmental support. The research intends to present firsthand solution proposals to the problems in the education provided for asylum seeker children. Results includes some clues on the relationship between mass migration, and education.

\section{Introduction}

Syrian Civil War has caused one of the biggest humanitarian crises after World War II. Many people including children, died during the clashes. The war also caused to displacement of millions. The migration of these people, also known as Syrian refugees/immigrants in various studies, has caused financial, economic, and sociocultural problems in many countries. Turkey has been significantly affected by these people's migration were legally statused as asylum seekers.

Turkey is situated on major migration routes. During the Syrian Civil War, Turkey's open-

\footnotetext{
*Correspondency: duranmavi@hotmail.com
} 
door policy saved the Syrian's life. There are around 3.5 million Syrians in Turkey according to official figures (Erdogan, 2020). So much so that, one of every two Syrians who had to leave their country is in Turkey (Cerna 2019, p. 10). At the beginning of this period, Turkey did not have much difficulty in providing the needs of the Syrian asylum seekers. But, the increasing number of asylum seekers has caused the opportunities provided by Turkey to be insufficient. The increase in the probability of permanent Syrian asylum seekers, and the rapid increase in the number of Syrians outside the camps necessitated the revision of the basic services. For this reason, regulations have been made in various areas, including services such as sheltering, health, and security. Education of Syrian asylum seekers is one of the services considered in this context. In order to provide a better-quality education to Syrian asylum seeker children, schools which called temporary education centers (TECs) were established.

TECs are schools established in Turkey by Turkish government for Syrian asylum seeker children's education. With TECs, it has been tried to educate Syrian children who did not go to school before or only educated in camps effectively. In addition, it is aimed to eliminate the poor-quality problem in the education of Syrian children. But crowded classrooms, and poor curriculum have made the functionality of TECs questionable (Kardes \& Akman, 2018; Kaya, 2019). Because of these, and other reasons, the concept of TECs was reorganized in 2016. With this new paradigm, it is aimed that asylum seeker children who have completed their education in TECs continue their education with peers in local schools (Alev \& Kara, 2021). In this way, it has been tried to prevent the negativities such as increase in crime, and unemployment rates, unplanned urbanization, and the absence of equity in public services that arise with migration in the future (Tasdan et al., 2016). Despite the revisions, TECs are still trying to solve physical, financial, and employee related problems (Gurel \& Buyuksahin, 2020). This gives clues about TECs, which are seen as an original model in the education of asylum seeker children (Aras \& Yasun, 2016), have some disadvantages those need solution.

Studies show that there were various problems that affect the TECs. One of these is lack of the employees (Guida, 2016). Therefore, it can be seen that non-educator employees are hiring for educational services. In addition, inadequacy of physical facilities (Usta et al., 2018), curriculum problems (Kaya, 2019; Kilcan \& Simsek, 2021), the ineffective use of Turkish language (Beyhan \& Epcacan, 2018; Kan \& Utlu, 2017), and social inclusion challenges (Gumus et al., 2020) negatively affect the performance of TECs. The continuation of all these disadvantages gives the idea that the developed revisions are not effective enough. However, mass migrations (Cerna, 2019; Sander et al., 2017), and the education of refugees (Dryden-Peterson, 2016), which affect many to countries, are among the issues that need to be examined in terms of Turkey.

In this research, it is aimed to explore the disadvantages of TECs, and develop solutions proposals which provide educational services to Syrian asylum seeker children. For this, the views of the educators working in a TEC were consulted. With this approach, perspectives of educators who share the same fate with asylum seeker children, and speak the same language were investigated. In the literature, it is seen that studies on Syrian asylum seeker children focus on issues such as inclusive education (Egitim Reformu Girisimi [ERG], 2018; Kahriman Pamuk \& Bal, 2019; Topaloglu, 2020), problems (Tanrikulu, 2017; Taskin \& Erdemli, 2018), social change (Veale, 2020), and policies (United Nations Children's Fund [UNICEF], 2017). In addition, studies (Acik Toplum Vakfi [ATV], 2015; Gurel \& Buyuksahin, 2020) that make general examinations about TECs are also seen. Especially existence of reports prepared by national, and international organizations (Erdogan, 2020; ERG, 2018; Human Rights Watch [HRW], 2015) draws attention. Notwithstanding there are 
limited studies in which both the disadvantages of TECs, and the solution proposals are discussed based on the opinions of Syrian, and Turkish educators. By this research, it was desired to eliminate this limitation regarding the TECs. Moreover, with the help of the research, it was aimed to increase the awareness of the educators, and policy-makers about phenomenon of migration, and asylum seekers' education.

\section{Conceptional framework}

\section{Asylum seekers' education in Turkey}

The Convention on the Rights of the Child, ratified by Turkey in 1995, stipulates that states parties provide educational services for all children. The Constitution of the Republic of Turkey includes this provision as a law, and it is a legal obligation to provide educational services for Syrian asylum seeker children. This obligation, pushes the legislative, and executive authorities to take the necessary steps.

Educational services carried out in asylum seeker camps in cooperation with Disaster, and Emergency Management Presidency, UNICEF, and Turkish Ministry of National Education (MoNE) in the first years of the Syrian Civil War. But, due to massive migration, educational activities started to be performed outside the camps after 2013. According to official authorities, almost all Syrian asylum seekers continue their lives in cities (www.goc.gov.tr). This shows the challenges of educational services offered outside the camps.

\section{TECs}

TECs are schools that established in Turkish cities following the Syrian War, and managed by administrators called coordinators. In TECs, Syrian asylum seeker educators, and Turkish coordinators work collaboratively. These schools are providing Arabic education at primary school level with Turkish language education. TECs, whose number exceeds 300, provide education services to thousands of children (Cerna, 2019). But, in Turkey it is also known that almost 400.000 Syrian asylum seeker children cannot go to school (UNICEF, 2017). Therefore, TECs have been revised in a way that will serve the participation of Syrian asylum seeker children into Turkish education system with the reorganization made in 2016 .

In TECs, efforts are made to minimize the damage caused by war, and migration. Additionally, in TECs preventive activities are executed targeting possible future problems (Tasdan et al., 2016). It is seen that TECs was an extraordinary education service approach for countries exposed to mass migration like Turkey. To this end, it is a meaningful act to address the problems faced by the educators working in TECs. Because, there are disadvantages of differing sorts in TECs (Sunata \& Abdulla, 2020). Increasing the performance of TECs requires examining mentioned disadvantages.

\section{Disadvantages in TECs}

TECs are trying to overcome many problems on the one hand, and to serve on the other. Limited parental support, student absenteeism, and adaptation issues are observed as the most common disadvantages that aforesaid coordinators deal with. TECs have severe issues related to professional development, and classroom management (Balkar et al., 2016). Overcrowded classes, and curriculum problems are other issues impacting education in TECs (Gumus et al., 2020). In addition, there are a number of physical handicaps that affect TECs. 
The physical handicaps of TECs buildings can be expressed as one of the most obvious problems affecting them. As a matter of fact, the majority of TECs serve in schools used by Turkish students. However, since these buildings belong to other schools, TECs start their services when Turkish students finish their activities (Eryaman \& Evran, 2019). The rest of TECs are located in buildings that are either renovated or leased. Lack of playgrounds, and distance from school building to where Syrian asylum seeker children live directly affect the quality of the education in TECs (Guida, 2016). Furthermore, TECs cannot respond to the special education needs of students nor can they provide any support for gifted children. It can be said that this is related to policies that give priority to the integration of asylum seeker children. Another issue that negatively affects TECs, and is closely related to physical facilities is financial problems.

Syrian asylum seeker parents who have financial problems do not send their children to TECs. Parents' this approach results with child labor, and early marriages (HRW, 2015). It is known that many asylum seekers go to work instead of going to school. Furthermore, the number of asylum seeker parents who are not interested to the educational services is still undeniably high because of financial problems. Nevertheless, the disadvantages of learning Turkish, and using it effectively exhaust TECs at least as much as the financial disadvantages.

Syrian asylum seeker children start their education in TECs without Turkish language (Balkar et al., 2016). This negatively affects the education (Nusche, 2009), and its social dimensions. Because language problems can prevent children from making new friends even causing them to leave school (Demir, 2015). Absence of sufficient skill of Turkish language is a serious problem for Syrian asylum seekers. In TECs, Turkish language lessons are given by primary school teachers. But these teachers' professional backgrounds might be a negative determinant in the effectiveness of Turkish language education. As in other educational services, motivation is an important factor in learning a foreign language (Wen, 1997). Here it can be said that asylum seeker children's problems reduce motivation, which negatively impacts academic performance. Considering all these together with other disadvantages, and solutions, it can be said that it would be suitable to conduct a research on TECs.

In the current research, it is aimed to investigate to disadvantages, and solution proposals about these disadvantages of TECs. For this, the opinions of educators working in TECs were consulted. Thus, it is aimed to reflect the contributions of educators who share a common fate with Syrian asylum seeker children into practice. Migration, affecting number of countries worldwide, has made the issue of educating asylum seeker children more debatable. It is predicted that the number of people exposed to mass migration will further rise (Sander et al., 2017). Accessing to educational services benefits not only them but also the local citizens (Dryden-Peterson 2016, p. 479; Dustmann \& Glitz, 2011; Lance, 2011). Therefore, their education attracts more attention than before.

Several studies about asylum seeker children's education demonstrate the importance of this subject in national, and international perspective (Cerna, 2019; Eryaman \& Evran, 2019; Gumus et al., 2020; Sunata \& Abdulla, 2020). When the limitations of the studies in which TECs are handled with this approach are added to this, the contributions of the current research to the literature becomes clearer. Therefore, addressing the problems with TECs model in Turkey, which are one of the stops for asylum seeker children, will be of benefit for researchers, and practitioners. Doing this could ease overcoming the problems for both the educators, and countries concerned. 


\section{Aim of the research}

This research aimed to explore the problems in TECs, and educators' solution proposals about these problems. Studies on Syrian asylum seeker children focus on cultural adaptation (Tanriverdi \& Ulu, 2020), education (Guida, 2016), integration (Ortadogu Stratejik Arastirmalar Merkezi [ORSAM], 2016), and TECs (Balkar et al., 2016; Kaya, 2019). In the context of TECs several investigations about educator perceptions (Isik \& Kaynak, 2018), difficulties (Beyhan \& Epcacan, 2018; Demirci, 2015; Kan \& Utlu, 2017), Turkish language teaching experiences (Eryaman \& Evran, 2019), and children's conditions (Gumus et al., 2020) were employed. However, it is seen that the studies examining the disadvantages of TECs according to Syrian asylum seeker educators, and TECs coordinators are limited. This suggests that there is a gap in the relevant literature. Therefore, the current research purposes to fill this gap. It is believed that the solution proposals of employees, who have witnessed the conditions of asylum seeker children closely, will make significant contributions to the disadvantages in their education. In this context, following questions were answered:

'By stating your solution proposals:

(1) What educational services do you conduct in your institution?

(2) Could you give information about the social, and cultural opportunities?

(3) What do you think about the environmental support offered?

(4) Could you give information about the Turkish language education?'

\section{Methodology}

\section{Design}

Phenomenology design, one of the qualitative research designs was adopted in this research. The qualitative research method seeks to examine in detail the views, and experiences of participants (Merriam, 2018, p. 24-25; Ozdemir, 2010, p. 334). In the current research, it is purposed to reveal the disadvantages in TECs, and to determine the solution proposals. These provide a suitable background for using phenomenology in the current research (Yildirim \& Simsek, 2016, p. 69). As a matter of fact, the nature of phenomenology is suitable to explore the lived experience (Patton, 2015, p. 115), and facilitates the discovery of the ideas of the participants as in this study.

\section{Participants}

In this research convenience sample approach were used for gathering data. Convenience sample approach is carried out with easily accessible participants (Patton, 2015, p. 309) as in the current research. Reasonable participants were identified in this research based on the scope of the phenomena, and the interests of stakeholders (p. 314). Particularly, the unwilling attitudes of Syrian asylum seeker educators to participate in the research was crucial in this adoption. In order to overcome negative attitudes of the participants', preliminary interviews were held. During these interviews they were ensured about research confidentiality. In this way, it is aimed to use the views of practical participants, to provide useful information from the research questions (Creswell, 2011, p.145-146), and to make indepth analyzes (Ozdemir, 2010, p. 334). After these procedures, research was employed with six participants working in a TEC located in Elbistan district of Kahramanmaras province in Turkey. Table 1 shows the information of these participants. 
Table 1. Participants' informations.

\begin{tabular}{llllllll}
\hline No. & Gender & Age & Branch & Education & Marital Status & Country & Code Name \\
\hline 1 & Female & 47 & English & Bachelor's & Married & SY & Educator-1 \\
2 & Male & 57 & Primary & Bachelor's & Married & TUR & Coordinator-1 \\
3 & Female & 40 & Literature & Bachelor's & Married & SY & Educator-2 \\
4 & Male & 50 & Literature & Associate Degree & Married & SY & Educator-3 \\
5 & Male & 60 & Science & Bachelor's & Married & SY & Educator-4 \\
6 & Male & 31 & Turkish & Bachelor's & Single & TUR & Coordinator-2 \\
\hline
\end{tabular}

As seen in Table 1, the participants are in the 31-60 age range. Except one all participants hold bachelor's degree, and only one participant is single. Two participants are Syrian however four are Turkish. Educators were coded as Educator-1, Educator-2..., coordinators as Coordinator-1, and Coordinator-2 for analyzes.

\section{Data collection, and tool}

It's known that one of the most convenient way of collecting data in phenomenological studies was interviewing (Yildirim \& Simsek, 2016, p. 71). Therefore, the data of the research were obtained by using a semi-structured interview form developed by author. With the permission from the participants, the data of the research were gathered through face-to-face interviews. The interviews took 13-23 minutes. They were recorded with voice recorders so that they could be transcribed later. Voice recorders were turned off when participants requested. When needed, notes were taken with permission of participants, and sub-questions were posed. During the interviews, an educator who could speak Turkish, and Arabic well supported the researcher. All interviews were completed during working hours in the TEC building.

\section{Data analysis}

The analysis of this research was performed in three stages, inspired by the technique developed by Miles and Huberman (1994). In this context, first (i)coding, then (ii)theming, and finally (iii)visualization stages was carried out. For the coding of the interviews descriptive coding technique was used. The codes here actually reflect the identity of the analysed content (Tesch, 1990, p. 119), and they were organized to creating themes, and subthemes. In this context during the analyzes, the textural (experiences), and structural (contextual [environment, conditions, way of experiencing]) descriptions, which were stated by Creswell (2013) as the steps of the phenomenological pattern, were concentrated. Thus, it was ensured that repeated experiences, and opinions become meaningful (DeSantis \& Ugarriza, 2000, p. 362). Finally, themes, and sub-themes were visualized.

\section{Reliability, and validity}

The research is based on the volunteering of all participants. It was stated to the participants that their identities will be kept, and views will be used for scientific aims. The data were $(i)$ obtained from a group reflecting the purpose of the study, and (ii)organized in a way that other researchers could understand increased the reliability of the study. Before, and during the interviews, the principles regarding the content, scope, audio recording, and notetaking of the research were explained. Notes were also taken contained the gestures, and mimics of participants during voice recordings. These notes were frequently used when transcribing. In this way, consistency of data was attempted to be increased. Sub-questions were used with a view to eliminating a loss of meaning, and to be able to uncover details too. In addition, block quotations were made when necessary to increase the credibility. 


\section{Findings}

Findings show that the themes created as a result of coding processes are ranked (i)educational services, (ii)social, and cultural opportunities, (iii)support, and (iv)Turkish language education. Educational services, one of these themes, refers to the general conditions of education served to asylum seeker children. Social, and cultural opportunities theme reflects the aspects of sociocultural practices experienced in TECs. The theme of support contains support for Syrian asylum seeker children, and educators. The theme of Turkish language education about Turkish learning processes. Each of the themes consists of sub-themes named (a)possibilities, (b)disadvantages, and (c)solutions. Here, possibilities mean the opportunities, and advantages; disadvantages mean the problems, and difficulties; solutions mean the suggestions.

\section{Educational services}

The participants' responses to the question 'What educational services do you conduct in your institution?', and their solution proposals were organized as in Figure 1.

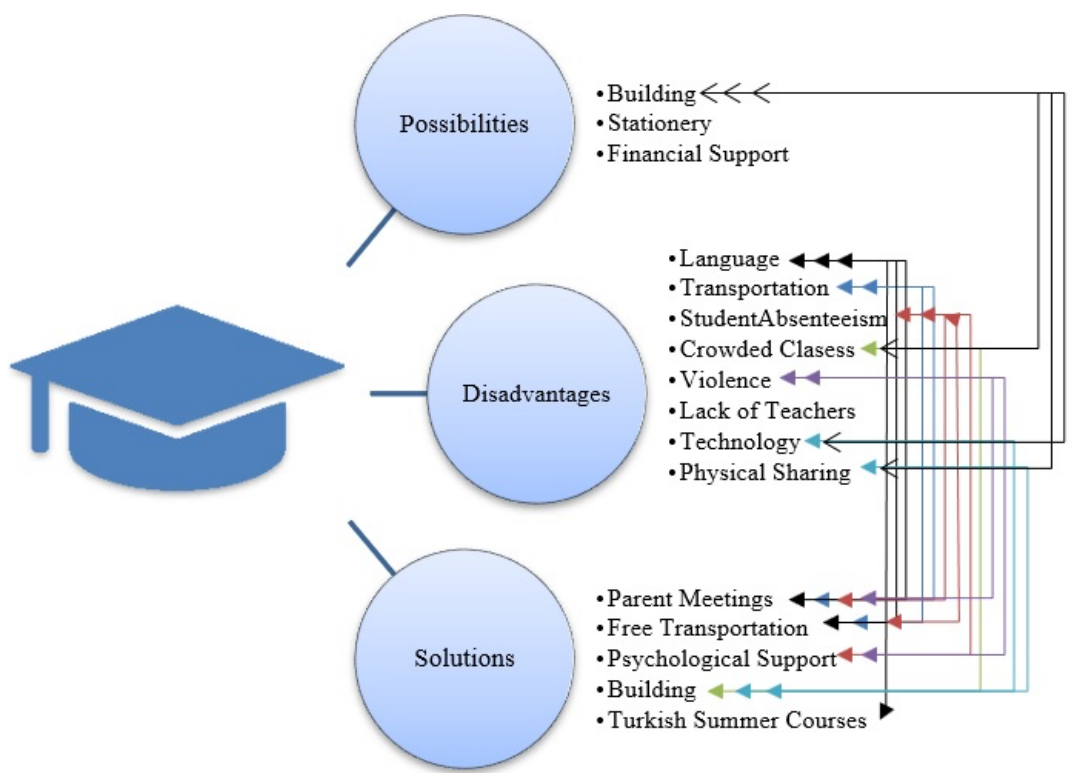

Figure 1. Codes pertaining to educational services

Note: Arrows show disadvantages, and related solution proposals.

As in Figure 1, according to the participants' opinions, sharing the available facilities with another public school was a major limitation. Despite that the participants pronounced they were generally satisfied with the facilities.

Participants emphasized having to use the same building with another school resulted in many problems. Educator-3 noted this situation negatively affected the quality of educational services. According to Coordinator-2, the major problem in the TEC is the language problem: 'The biggest problem of our children, and educators is Turkish.' Besides, the participants shared they did not have a lack of educational materials. The educator participants said that they were allowed to use the smart boards in a limited way. Coordinator-1 agree with educators about the use of facilities such as playground, and toilets. He also pinpointed he could not get rid of the feeling of a guest no matter what he did. Educator-1 underpinned the 
school was far from where Syrian asylum seeker children lived, and this affected to children's opportunities, and absenteeism. Educator-4 summarized the effects of children's experiences on educational services as follows:

"What concerns me is the effects of the war. Of course, I am trying to find humble solutions to these as much as I can. I speak to the kids. This situation $<<$ negative effects of war $>>i s$ observed frequently in classrooms. It is not easy to teach $<<$ something $>>$ children who have fled the war. These are the solutions that I myself could find. Discipline problems arise from time to time in the classroom. Kids are quite prone to peer violence. We get over it by talking, but they don't listen. I wish we had a school psychologist."

All participants agreed a school building may prevent so many problems. Coordinators believe that parental services (Turkish education, seminars, announcements etc.) will positively affect TEC performance. The need for, and possible contributions of guidance, and psychological counselling services have been expressed by all educators.

\section{Social, and cultural opportunities}

The participants' responses to the question 'Could you give information about the social, and cultural opportunities?', and solution proposals were organized as in Figure 2.

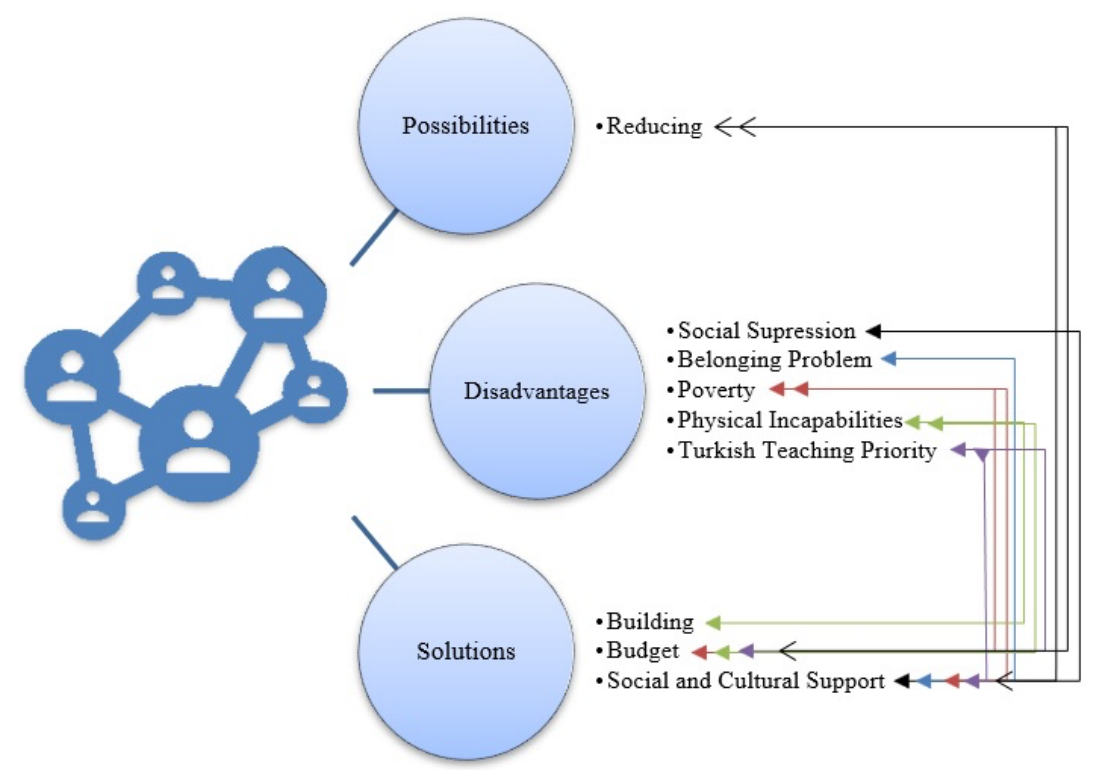

Figure 2. Codes for social, and cultural opportunities

Note: Arrows show disadvantages, and related solution proposals.

As in Figure 2, the participants highlighted they had limited social, and cultural opportunities. Nonetheless, they also voiced they were thankful for these opportunities.

Generally, the participants had the sense that education was attributed more importance than social, and cultural activities. Participants reported that social, and cultural activities for children were organized just as part of $<<$ April 23 $>>$ National Sovereignty, and Children's Day. Educator-4's views on social, and cultural opportunities were as follows: 'I do not think Turkish children, and their parents, and educators will be satisfied.'. Coordinator-1 stated they were guests in the current school. He also stated 'familyism-tribalism' was popular 
among children, which prevented school-wide social, and cultural activities from being held. Educator-3, who used to work as literature teacher in Syria before the war, have opinions as follows:

"Most of our work is about reading, and writing. Of course, we do something else in the remaining times. These children were unable to reach to their schools due to war. We take care of them. We do simple activities, and competitions in the classroom, but we cannot hold school-wide activities. The limited budget, time, and environment $<<$ talking thoughtfully $>>$ do not allow us. Unfortunately..."

Considering the participants' solution proposal for social, and cultural activities, the one underlined by all of them was increasing TECs' budgets. The coordinators are held this view. All participants agree that the improvement of physical conditions will positively affect social, and cultural activities.

\section{Support}

The participants' responses to the question 'What do you think about the environmental support offered?', and solutions proposals were organized as in Figure 3.

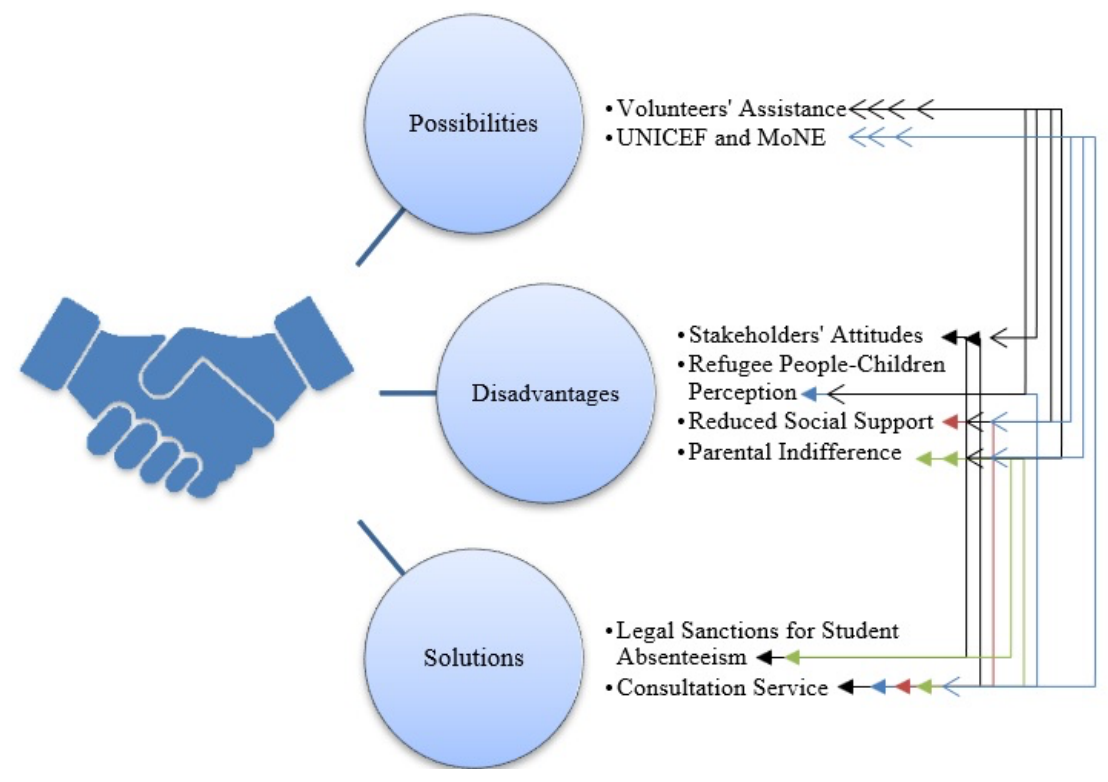

Figure 3. Codes for support

Note: Arrows show disadvantages, and related solution proposals.

As seen in Figure 3, all participants emphasized they were highly satisfied with the support provided for them by the UNICEF, and MoNE. In addition, the participants report that they are satisfied with the support provided by the stakeholders.

Educator-1 underlined she was a Muslim, pleased with the support offered to her. However, she added there was an increase in the number of people who ignored her. Educator-2 put forward her point of view on environmental support as follows: 'Sometimes problems occur. Those problems may arise anywhere. $<<$ Referring to discrimination $>>$ Syrian, Turkish... there is no such thing! I mean, those problems will surely arise.'. Educator-2 stated that there is no problem-free school or institution. Educator-3 discussed the problems, and explained the support which provided by parents to her school, and children as follows: 
'We came from the same country as the parents of our children, but we cannot communicate with each other much. $<<$ Referring to the participants $>>$ we, and $<<$ referring to the parents $>>$ they work under very hard conditions. Many parents don't even care about school.'. Coordinator-1 stated 'If UNICEF did not support to us, the TEC, which already had limited environmental opportunities, would be in a worse situation.'.

Coordinator-1 stated 'If UNICEF did not support to us, the TEC, which already had limited environmental opportunities, would be in a worse situation.'. As regards children's school attendance, Coordinator-1 said they were unable to get any support from other stakeholders. Educator-4, the oldest, and most experienced educator in the TEC, said both educators, and children needed psychological help. All participants think that there is not as much environmental support as in the first times.

Educator-4 highlighted parents seriously needed consultation services. He also argued psychological help should be provided for the educators, and children. All participants, especially the coordinators, mentioned the necessity of legal regulations to increase children's school attendance.

\section{Turkish language education}

The participants' responses to the question 'Could you give information about the Turkish language education?', and their solutions were organized as in Figure 4.

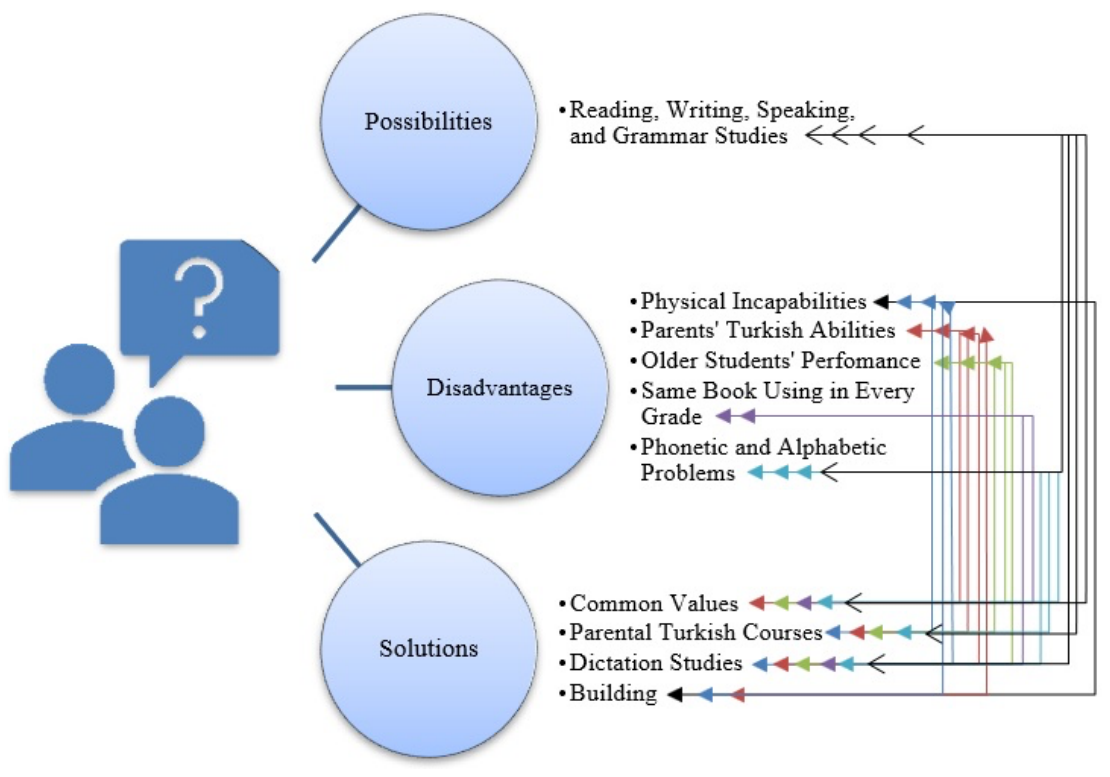

Figure 4. Codes for Turkish language education

Note: Arrows show disadvantages, and related solution proposals.

As in Figure 4, the participants focus on Turkish language education. Participants state that a significant part of the lessons about Turkish language teaching. Even so, they thought that was an obligation.

All participants stated younger children were more successful at Turkish language education than older's. According to Educator-1, a Syrian Turkmen who used to live in a city very close to the Turkish border of Syria, the lack of an independent building negatively affects the 
activities conducted for Turkish language education. Educator-2, who works as a translator, states that alphabetical differences negatively affect Syrian asylum seeker children's Turkish learning process similarly with Coordinator-2. However, Educator-2, who says that there are many similar words in Turkish, and Arabic. She lists the problems as follows:

"They also have problems with vowels. Children are having hard times with vowels $<<$ they forget to write some vowels $>>$. (...) The verb comes at the beginning of the sentences in our language $<<$ Arabic $>>$; but at the end of the sentences in yours $<<$ Turkish $>>$. I spent all day talking about this today. I put the verb at the end $\langle<$ of the sentence $>>$. But children were unable to write what they heard again. Another problem is that Arabic $<<$ alphabet $>>$ does not have $i, j, \ddot{o}$, and $\ddot{u}$ letters. What I mean is some sounds, and letters do not exist in Arabic."

During the interviews, Educator-3 states that unlike Arabic, Turkish is written from left to right, and mentioned limited number of parents help their children to learn Turkish. However, he criticizes various digital applications about Turkish language used by parents for homeworks. Educator-4, who is a science teacher, said that he executed his lessons in Arabic, and he cannot use Turkish effectively. Similarly, Coordinator-2, reported that he did not know Arabic. He mentioned this may cause various problems in teaching Turkish to Syrian asylum seeker children. Coordinator-1 stated a number of children, and their parents were unwilling to learning Turkish. All participants indicated that children forgot vowels, and added extra consonants while writing.

All participants state that parents should also to be educate Turkish language in order to increase the quality of Turkish language education. Educators state that taking attention to familiar values of the two cultures will facilitate the solution of this problem. Providing suitable materials for children's level, and increasing the time allocated for dictation activities were other solution proposals offered.

\section{Conclusion, and Discussion}

In this research, four questions were answered. The first of these is 'What educational services do you conduct in your institution?'. Findings about this question shows that all participants believed well-equipped an independent building could affect educational services positively. It is known that educational institutions affect the quality of education offered, and the performance of educators (Senge, 2014). Similar with this findings, recent studies on the education of asylum seeker children supported this result (Balkar et al., 2016; Usta et al., 2018). The findings indicate that the problems experienced in the effective use of Turkish language are one of the important disadvantages of relevant TEC. This issue is also mentioned in various studies (Beyhan \& Epcacan, 2018; Eren, 2019) consistently with current research. It is understood from the findings that the Syrian asylum seeker educators feel like guests themselves. However, these views contradict the expectations that they will be permanent in Turkey (ORSAM, 2016). This contradiction makes the effectiveness of the efforts to solve the experienced problems questionable. Because in the current research the emotional, and psychological benefits of TECs are also criticized from time to time by all participants. This gives the idea that the TEC model still needs to be developed. The existence of psychological counselling services solution proposal in similar studies (Gurel \& Buyuksahin, 2020; Isik, \& Kaynak, 2018; Kagnici, 2017) also confirms this idea.

The second question sought to be answered in the research is 'Could you give information about the social, and cultural opportunities?‘. In the current research, all participants state 
that the social, and cultural opportunities offered to them are limited. Likewise, it was figured out the support provided by parents was limited because of financial problems (HRW, 2015; Topaloglu \& Ozdemir, 2020). Here, a more remarkable issue is this support is diminishing each day. In a study (Sleijpen et al., 2017), findings similar with current research were reported on support topic. This may be linked to the social pressure on Syrian asylum seekers in Turkey or to the asylum seekers' prioritizing economic concerns more than anything else. Here, there is a question that needs to be answered: 'Are the asylum seeker children being otherized in Turkey?' Participants think that Turkish language education constitutes the largest part of the studies in the relevant TEC. This part is one of the obstacles to doing social, and cultural activities desired. Several studies show that learning the language of the host country facilitated the integration of asylum seeker children (Pryor, 2001; Sunata \& Abdulla, 2020). Consistent with this, in the literature there are specific studies (Cerna, 2019; Tasdan et al., 2016) about integration which has social, and cultural components. All these results make TECs special institutions in the field of integration of asylum seeker/refugee/immigrant children. In the research, it was found peer violence among children, arising from familyismtribalism was a problem that needed to be overcome. This attitude which can also be called being a part of a gang can harm the relations of asylum seeker children among themselves, and with local children. Psychological support services were suggested by the participants as a solution proposal to such problems, as was disclosed by similar studies (Eryaman \& Evran, 2019; Guida, 2016.

Another question sought to be answered in the research is "What do you think about the environmental support offered?'. The current research points to significant support from international organizations such as UNICEF in critical areas such as materials, and educators' salaries (ATV, 2015). Similar supports are acknowledged given by the MoNE. When the literature is examined, it is seen that there are various studies whose results are in parallel with current research (Gumus et al., 2020; Icimizdeki Suriye, 2015). All these efforts show the importance given to education in solving the problems of asylum seekers. The crowded classes in the TEC, and Syrian children's insufficient knowledge of Turkish are the other striking findings of the research. These results similar with various studies (HRW, 2015; Sahin \& Sumer, 2018). In a limited number of studies (ORSAM, 2016), it is seen that transportation, finance, and psychological support problems are factors that reduce the quality of educational services, as in the current research.

The answers to the last question of the research, 'Could you give information about the Turkish language education?', contain remarkable results. Some participants put into words that children attained a sufficient level in speaking Turkish, but their reading, and writing skills were still not good. It is stated in various studies that phonetic-alphabetic difficulties (Demirci, 2005; HRW, 2015), and material deficiencies (Taskin \& Erdemli, 2018) make learning Turkish language difficult for asylum seekers. The fact that the alphabetical differences, and absence of capitalization-punctuation in Arabic may be important factors that prevent Syrian asylum seeker children's using Turkish effectively. Considering the problem that Arabic does not have vowels like $\imath, j, \ddot{o}, \ddot{u}$, the challenges in Turkish language education can be better analyzed. Aside from all these, parents' indifference to TECs, and to the learning of Turkish can be seen as another reason for this difficulty. The results in line with the studies showing that children who learn a foreign language at an early age are more successful (Munoz, 2006, Munoz, 2014) are also seen in the current research. This suggests that each day in the education of asylum seeker children can lead to irreparable pedagogical, and social consequences. 
It is seen that several studies have reached similar results with current research. However, the research differs from some of these (Aras \& Yasun, 2016) in that the data was obtained directly from a TEC. In the research, unlike various studies, only the knowledge of educators (Kardes \& Akman, 2018) or coordinators (Orucu, 2019) was not consulted, and the interviews were conducted with both educators, and coordinators.

In the research, unlike the studies in which only the views of Turkish participants were examined (Eren, 2019), Syrian asylum seeker educators' views were also examined. Syrian asylum seeker educators are individuals who share many experiences with Syrian children in, and outside TECs. In this respect, this research is a candidate to be among the limited studies in which the views of Syrian trainers in TECs are investigated (Balkar et al., 2016; Gumus et al., 2020; Usta et al., 2018). In some of the studies carried out with the participation of Syrian educators (Balkar et al., 2016), it is seen as a prerequisite condition for the participants to be able to understand/speak Turkish. However, there is no such prerequisite condition in this research. These characteristics reinforces the aforementioned candidacy.

The present research confirms its similarities with the part that includes educational disadvantages, and solution suggestions (Isik \& Kaynak, 2018; Kan \& Utlu, 2017; Usta et al., 2018). However, it is thought to differ from these studies with the themes of social, and cultural opportunities, and support. Thus, it is believed that it will contribute to the elimination of limitations in research on TECs, and asylum seeker/refugee/immigrant education. When the difficulties in the data collection process are added to all of these, it is believed that the research is expected to raise awareness to researchers, educators, and policy makers interested in migration.

This research is confined to the views of the educators, and coordinators of asylum seeker children in one of the TECs adopting a qualitative orientation. And it is possible that these results do not reflect other TECs' conditions exactly in Turkey. Therefore, it may not be correct to generalize the results. Taking into account the results, the following suggestions can be made: (i)Educational studies for the Turkish language education should be handled with an effective approach that includes parents. (ii)It may be appropriate for countries to prepare emergency education plans, covering education services such as TEC, to use in the face of mass migration. (iii)A similar, cross-cultural study can be conducted, which can also be designed as a longitudinal one.

\section{References}

Alev, S., \& Kara, M. (2021). The Relationship between cultural intelligence and the attitudes towards refugee students: A study on primary school teachers. Participatory Educational Research, 8(1), 109-122. https://doi.org/10.17275/per.21.6.8.1

Aras, B., \& Yasun, S. (2016, July). The educational opportunities and challenges of Syrian refugee students in Turkey: Temporary education centers and beyond. Istanbul Policy Center. Accessed from https://core.ac.uk/download/pdf/78366602.pdf in October 2021.

ATV. (2015, Kasim). Kayip neslin esiginde: Turkiye'deki Suriyeli multeci cocuk ve genclerin egitimde karsilastiklari zorluklar [On the verge of a lost generation: The educational challenges of Syrian refugee children, and youth in Turkey]. ATV. Accessed from https://www.stgm.org.tr/sites/default/files/2020-09/kayip-neslin-esigindeokuyamiyorum.-yazamiyorum.-okula-gitmek-istiyorum.pdf in October 2021. 
Balkar, B., Sevilay, S., \& Isikli Babahan N. (2016). Gecici egitim merkezlerinde gorev yapan Suriyeli ogretmenlerin karsilastiklari sorunlar [Problems confronted by Syrian teachers working at temporary education centers]. Journal of Theory and Practice, 12(6), 1290-1310.

Bansak, K., Hainmueller, J., \& Hangartner, D. (2016). How economic, humanitarian and religious concerns shape European attitudes toward asylum seekers. Science, 354(6309), 217-222. https://doi.org/10.1126/science.aag2147

Beyhan, D., \& Epcacan, C. (2018). Suriyeli ogrencilerin Turk egitim sistemine entegrasyonu projesi kapsaminda gecici egitim merkezlerinde gorev yapan dil ogreticilerinin dil ogretirken karsilastiklari sorunlar ve cozum onerileri [The problems that the language instructors encounter at the temporary training centre, and their suggesstions for solution in the scope of the project for integration of Syrian students into Turkish educational system]. Turkish Studies Educational Sciences, 13(19), 285-306. http://dx.doi.org/10.7827/TurkishStudies.14040

Cerna, L. (2019, May). Refugee education: Integration models and practices in OECD countries (Report: 203). OECD. https://doi.org/10.1787/19939019

Creswell, J. W. (2011). Educational research: Planning, conducting and evaluating quantitative and qualitative research $\left(4^{\text {th }} \mathrm{ed}\right.$.). Pearson.

Creswell, J. W. (2013). Nitel arastima yontemleri [Qualitative research methods] (M. Butun, \& B. Demir, Trans. Eds.). Siyasal.

Demirci, M. (2015). B1 seviyesinde Turkce ogrenen Suriyeli ogrencilerin sesli okuma becerisiyle ilgili tespitler [Determinations related to reading aloud skills of Syrian Turkish learning students in level b1]. International Periodical for the Languages, Literature and History of Turkish or Turkic, 10(7), 333-358. http://dx.doi.org/10.7827/TurkishStudies.8149

DeSantis, L., \& Ugarriza, D. N. (2000). The concept of theme as used in qualitative nursing research. Western Journal of Nursing Research, 22(3), 351-372. https://doi.org/10.1177/019394590002200308

Dryden-Peterson, S. (2016). Refugee education: The crossroads of globalization. Educational Researcher, 45(9), 473-482. https://doi.org/10.3102/0013189X16683398

Dustmann, C., \& Glitz, A. (2011). Migration and education. In E. A. Hanushek, S. Machin, \& L. Woessmann (Eds.), Handbook of the economics of education (pp. 327-439). Elsevier. https://doi.org/10.1016/B978-0-444-53444-6.00004-3

Erdogan, M. (2020, Temmuz). Suriyeliler barometresi 2019 [Syrians barometer 2019]. United Nations Commission on Human Rights. Accessed from https://www.unhcr.org/tr/wpcontent/uploads/sites/14/2020/09/SB2019-TR-04092020.pdf in October 2021.

Eren, Z. (2019). Yonetici ve ogretmen goruslerine gore gocmen cocuklarin egitim sorunlari ve cozum onerileri [According to principals, and teachers educational problems of immigrant children, and solutions]. Bolu Abant Izzet Baysal Universitesi Egitim Fakultesi Dergisi [Abant Izzet Baysal University Journal of the Faculty of Education], 19(1), 213-234. https://doi.org/10.17240/aibuefd.2019.19.3815-476805

ERG. (2018, December). Community building through inclusive education. ERG. Accessed from http://www.egitimreformugirisimi.org/wp-content/uploads/2017/03/SuriyeVeEgi timRaporENG.02.01.19.web-2.pdf in October 2021.

Eryaman, M. Y., \& Evran, S. (2019) Syrian refugee students' lived experiences at temporary education centres in Turkey. In K. Arar, J.S. Brooks, \& I. Bogotch, (Eds.), Education, immigration and migration (pp. 131-143). Emerald. https://doi.org/10.1108/978-178756-044-420191009

Guida, M. (2016, Temmuz). Turkiye'deki genc Suriyelilerin entegrasyonu [Integration of young Syrians in Turkey]. 29 Mayis Universitesi Siyaset Bilimi ve Uluslararasi 
Iliskiler Bolumu. Accessed from https://politics.29mayis.edu.tr/tr/haber/rapor-turkiyedeki-genc-suriyelilerin-entegrasyonu in October 2021.

Gumus, E., Kurnaz, Z., Esici, H., \& Gumus, S. (2020). Current conditions and issues at Temporary Education Centres (TECs) for Syrian child refugees in Turkey. $\begin{array}{llll}\text { Multicultural Education } & \text { Review, } & \text { 12(2), }\end{array}$ https://doi.org/10.1080/2005615X.2020.1756083

Gurel, D., \& Buyuksahin, Y. (2020). Education of Syrian refugee children in Turkey: Reflections from the application. International Journal of Progressive Education, $16(5), 426-442$.

HRW. (2015, November). When i picture my future, $i$ see nothing: Barriers to education for Syrian refugee children in Turkey. HRW. Accessed from https://www.hrw.org/sites/de fault/files/report_pdf/turkey1115_reportcover_web.pdf in October 2021.

Icimizdeki Suriye. (2015, Agustos). Gaziantep ortak akil raporu [Gaziantep common sense report]. (Report: 2). Gaziantep Ticaret Odasi. Accessed from https://www.gto.org.tr/up loads/1553073990245279.pdf in October 2021.

IMF. (2020, April). World economic outlook: The macroeconomic effects of global migration (Chapter: 4). IMF. Accessed from https://www.imf.org/ /media/Files/Publications/W $\mathrm{EO} / 2020 / \mathrm{April} /$ English/ch4.hx?la=en in October 2021.

Isik, S., \& Kaynak, U. (2018). Gecici egitim merkezlerinde calisan okul psikolojik danismanlarin Suriyeli multeci cocuklara yonelik algilarinin metaforla incelenmesi [A metaphorical analysis of perception of the school councellors working in the temporary education centers about the Syrian refugee children]. Journal of Turkish Educational Sciences, 18(2), 120-145. https://doi.org/10.37217/tebd.664177

Kagnici, D. Y. (2017). Suriyeli multeci cocuklarin kulturel uyum surecinde okul psikolojik danismanlarina dusen rol ve sorumluluklar [School counselors' roles, and responsibilities in cultural adaptation process of Syrian refugee children]. Elementary Education Online, 16(4), 1768-1776. https://doi.org/10.17051/ilkonline.2017.342990

Kahriman Pamuk, D., \& Bal, M. (2019). Okul oncesi ogretmenlerinin kapsayici egitimde cocuklarin dil gelisim surecine yonelik goruslerinin belirlenmesi [Identifying preschool teachers' opinions on the language development process of children in inclusive education]. Milli Egitim Dergisi [Journal of National Education], 48(1), 737754.

Kan, M. O., \& Utlu, G. (2017). Errors in case markers made by Syrian students who learn Turkish in temporary education center. Journal of Education and Training Studies, 5(9), 205-212. https://doi.org/10.11114/jets.v5i9.2562

Kardes, S., \& Akman, B. (2018). Suriyeli multecilerin egitimine yonelik ogretmen gorusleri [Teachers' views on the education of Syrian refugees]. Elementary Education Online, 17(3), 1224-1237. https://doi.org/10.17051/ilkonline.2018.466333

Kaya, A. (2019). Suriyeli multeci cocuklarin egitimi uzerine bir arastirma: Gecici egitim merkezleri ve mufredatlari [A research on the education of syrian refugee children: Temporary education centers, and curriculum] (537239) [Master thesis]. Marmara University. Council of Higher Education: Thesis Center.

Kilcan, B., \& Simsek, U. (2021). Investigation of social studies curriculum in regards to migrant, refugee, asylum-seekers concepts. Participatory Educational Research, 8(1), 395-408. http://dx.doi.org/10.17275/per.21.23.8.1

Lance, L. (2011). Nonproduction benefits of education: Crime, health and good citizenship. In E. A. Hanushek, S. Machin, \& L. Woessmann (Eds.), Handbook of the economics of education (pp. 183-282). Elsevier. Accessed from https://economics.uwo.ca/people/ lochner_docs/nonproductionbenefits_dec10.pdf in October 2021. 
Merriam, S. B. (2018). Nitel arastirma: Desen ve uygulama icin bir rehber [Qualitative research: A guide to design, and implementation] (S. Turan, Trans. Eds.; $3^{\text {rd }}$ ed.). Nobel.

Miles, M. B., \& Huberman, A. M. (1994). Qualitative data analysis: An expanded sourcebook ( $2^{\text {nd }}$ ed.). Sage.

Munoz, C. (2006). The effects of age on foreign language learning: The BAF project. Age and the rate of foreign language learning, 19, 1-40. https://doi.org/10.21832/9781853 598937-003

Munoz, C. (2014). Exploring young learners' foreign language learning awareness. Language Awareness, 23(1-2), 24-40. https://doi.org/10.1080/09658416.2013.863900

Nusche, D. (2009). What works in migrant education? A review of evidence and policy options (Report: 22). OECD. http://dx.doi.org/10.1787/227131784531

ORSAM. (2016, Ocak). Turkiye'deki Suriyeli siginmacilar: Uzun vadeli entegrasyon icin firsatlar ve zorluklar [Syrian refugees in Turkey: Opportunities, and challenges for long-term integration]: Uzun vadeli entegrasyon icin firsatlar ve zorluklar (Report: 1). ORSAM. Accessed from http://orsam.org.tr/d_genel/1tr.pdf in October 2021.

Orucu, D. (2019), There is always light at the end of the tunnel: Emotions of a Turkish school leader in a temporary education center for Syrian children. In I. Oplatka, \& K., Arar, (Eds.), Emotion management and feelings in teaching and educational leadership (Studies in educational administration) (pp. 193-212). Emerald. https://doi.org/10.110 8/978-1-78756-010-920191017

Ozdemir, M. (2010). Nitel veri analizi: Sosyal bilimlerde yontembilim sorunsali uzerine bir calisma [Qualitative data analysis: A study on methodology problem in social sciences]. Eskisehir Osmangazi Universitesi Sosyal Bilimler Dergisi [Eskisehir Osmangazi University Journal of Social Sciences], 11(1), 323-343.

Patton, M. Q. (2015). Qualitative research and evaluation methods (4 ${ }^{\text {th }}$ ed.). Sage.

Pryor, C. (2001). New immigrants, and refugees in American schools: Multiple voices. Childhood Education 77(5), 275-283. https://doi.org/10.1080/00094056.2001.105216 50

Sahin, S., \& Sumer, S. (2018). The problems experienced in the integration process of Syrian students into the Turkish education system. Universal Journal of Educational Research, 6(5), 909-918. https://doi.org/10.13189/ujer.2018.060512

Sander, N., Abel, G., Riosmena, F., Lutz, W., Butz, W. P., \& KC, S. (2017). The future of international migration. In W. Lutz, W. P. Butz, \& S. KC. (Eds.), World population and human capital in the twenty-first century (pp. 333-396). Oxford.

Senge, P. (2014). Ogrenen okullar: Egitimciler, veliler ve egitimle ilgilenen herkes icin bir besinci disiplin alan kitabi [The fifth discipline fieldbook for educators, parents, and everyone who cares about education] (M. Cetin, Trans. Eds.; $2^{\text {nd }}$ ed.). Nobel.

Sleijpen, M., Mooren, T., Kleber, R. J., \& Boeije, H. R. (2017). Lives on hold: A qualitative study of refugees' resilience strategies. Childhood, 24(3), 348-365. https://doi.org/10.1 $177 / 0907568217690031$

Sunata, U., \& Abdulla, A. (2020). Lessons from experiences of Syrian civil society in refugee education of Turkey. Journal of Immigrant \& Refugee Studies, 18(4), 434-447. https:// doi.org/10.1080/15562948.2019.1692984

Tanrikulu, F. (2017). Turkiye'de yasayan Suriyeli cocuklarin egitim sorunu ve cozum onerileri [Education problem of the Syrian children living in Turkey, and solution proposals]. Liberal Dusunce Dergisi [Journal of Liberal Thought], 86, 127-144.

Tanriverdi, A., \& Ulu, M. (2020). Gecici koruma altina alinan Suriyelilerde goc, kulturlesme/kulturel uyum ve din iliskisi: Kayseri ornegi [The relationships between 
migration, acculturation, and religion among Syrians under temporary protection: A case study of Kayseri]. Bilimname, 43, 169-212. https://doi.org/10.28949/bilimname.7 76819

Tasdan, C., Colpan Kavuncu, A., Akbulut, A. M., Irdem, I., Osmanoglu, E., Ozkaya, O., \& Yildiz, A. K. (2016, Kasim). I. Uluslararasi goc ve guvenlik konferansi sonuc raporu [Concluding report of the I. International migration and security conference] (Report: 6). Polis Akademisi Guvenlik Bilimleri Enstitusu Goc ve Sinir Guvenligi Arastirma Merkezi, Ankara, Turkiye.

Taskin, P., \& Erdemli, O. (2018). Education for Syrian refugees: Problems faced by teachers in Turkey. Eurasian Journal of Educational Research, 18(75), 155-178. https://doi.org /10.14689/ejer.2018.75.9

Tesch, R. (1990). Qualitative research: Analysis types and software tools. Falmer.

Topaloglu, H. (2020). Multecilerin sosyal icerilmeleri baglaminda egitime erismelerinde yasanilan problemler ve cozum onerileri [Problems in and solution proposals for accessing education in the context of social inclusion of refugees] (664546) [Doctoral dissertation]. Hacettepe University. Council of Higher Education: Thesis Center.

Topaloglu, H., \& Ozdemir, M. (2020). Multecilerin egitime erismeleri surecinde yasadiklari sorunlar ve sosyal icerilme beklentileri onerileri [Problems the refugees face during access to education and their social inclusion expectations]. Electronic Turkish Studies, 15(3), 2031-2059.

UNICEF. (2017, April). Turkiye'de 'kayip bir kusak' olusmasini engellemek [To prevent the formation of a 'lost generation' in Turkey]. UNICEF. Accessed from https://www.unic ef.org/turkey/media/5361/file/Türkiye \%27deki\%20Suriyeli\%20Çocuklar\%20Bilgi\%2 0Notu\%20Ocak\%202017.pdf in October 2021.

Usta, M. E., Arikan, I., Sahin, Y., \& Cetin, M. S. (2018). Suriyeli egitimcilerin gecici egitim merkezlerinde karsilastiklari sorunlarin incelenmesi [Perspectives of Syrian educators on problems faced during their training in temporary education centres]. Mukaddime, 9(1), 173-188. https://doi.org/10.19059/mukaddime.341921

Veale, A. (2020). Conflict-driven social change: The case of Syrian children and youth. Current Opinion in Psychology, 35, 114-118. https://doi.org/10.1016/j.copsyc.2020.06 .001

Wen, X. (1997). Motivation and language learning with students of Chinese 1. Foreign language annals, 30(2), 235-251. https://doi.org/10.1111/j.19449720.1997.tb02345.x

Yildirim, A., \& Simsek, H. (2016). Sosyal bilimlerde nitel arastirma yontemleri [Qualitative research methods in the social sciences] $\left(10^{\text {th }}\right.$ ed.). Seckin. 